\title{
Sağlık Bilimleri Öğrencilerinin Sigara İçme Durumu, Etkileyen Faktörler ve İkincil Sigara Dumanı ile İlgili Farkındalık Düzeyleri
}

\author{
Factors Affecting Smoking and Awareness of Secondhand Smoke \\ Among Health Science Faculty Students
}

\author{
Merve KAYA ${ }^{\circledR}$, Ayşe ERGÜN ${ }^{\oplus}$
}

öz

\begin{abstract}
Amaç: Çalışma sağlık bilimleri öğrencilerinin sigara içme durumlarını, ikincil sigara dumanı ile ilgili farkındalık düzeylerini ve bunları etkileyen faktörleri belirlemek amacıyla yapıldı.

Yöntem: Tanımlayıcı olarak planlanan araştırma, istanbul'da bir devlet üniversitesinin sağılı bilimleri fakültesindeki 1054 öğrenci ile yapıldı. Veriler Sosyodemografik Form, ikincil Sigara Dumanı Anketi, Sigara Içiciliği Anket Formu ve Fagerström Nikotin Bağımlıık Testi ile toplanıp, tanımlayıcı istatistikler ve Kikare analizi ile değerlendirildi.

Bulgular: Öğrencilerin yaş ortalaması $20.06 \pm 1.66$ ve \%84.5'i kadındı. Sigara içme sıklığı \%13.9, son 30 gün içerisinde ikincil sigara dumanına maruz kalma sıklığı \%96.9'du. Ev (\%24.2) ve okulda (\%26.7) ikincil sigara dumanı maruziyeti vardı. Sigara içen öğrencilerin \%41.6'sı sigara bağımlısı olduğunu düşünürken, Fagerstrom Nikotin Bağımlıık Testi'ne göre \%90.8'i orta, yüksek ya da ağır düzey sigara bağımlısıydı. Sigara bırakmayı düşünenlerin oranı \%50.7 idi. Erkek öğrencilerde, düşük gelir düzeyine ve boşanmış ebeveynlere sahip, yalnız veya arkadaşları ile birlikte öğrenci evi/yurtta yaşayan ve çalışanlar öğrencilerde sigara içme sıklığı istatistiksel olarak anlamlı diğerlerinden yüksekti.

Sonuç: Çalıșmada, ikincil sigara dumanı maruziyetinin yüksek olduğu ve sigara içen öğrencilerin hemen hemen hepsinin bağımlılık düzeyinin orta ve üstünde olduğu belirlendi. Sigaraya başlama yaş ortalamasının üniversite yıllarına rastladığı saptandı. Bu sonuçlar doğrultusunda üniversitenin ilk yıllarında ikincil sigara dumanı maruziyetini de içeren sigara önleme ve bırakma programları yapılması önerilir.
\end{abstract}

Anahtar kelimeler: Çevresel sigara dumanı, ikincil sigara dumanı, sigara, tütün

\section{ABSTRACT}

Objective: The aim of this research was investigeted smoking prevalence, affecting factors and awareness of secondhand smoking among health science students.

Method: This descriptive study was conducted with 1054 students of a Health Sciences Faculty in Istanbul. Data were collected by Sociodemographic Form, Secondhand Smoke Exposure Questionnaire Form, Cigarette Smoking Questionnaire Form and Fagerstrom Nikotine Dependence Test and were evaluated by chi-square test and descriptive statistic analysis.

Results: The average age of the students was $20.06 \pm 1.66$ and students of $84.5 \%$ were female. For students, the frequency of smoking was $13.9 \%$ and the frequency of exposure to secondhand smoke was $96.9 \%$ during the last 30 days. They were exposure secondhand smoke at home (24.2\%) and at school (26.7\%). According to Fagerstrom Nikotine Dependence Test, $90.8 \%$ of smoker students were medium, high or heavy smoking addicts. Rate of wanted to quit smoking was $50.7 \%$. The frequency of smoking was statistically significant and higher in men, low-income, children of devorced parents, living alone or together with friends in student houses/dormitoris and working in a paid job than the others.

Conclusion: According to this study result, secondhand smoke exposure was high and the addiction level of almost all students who smoke was medium and above. It is found that theage of starting to smoke coincided with the university years. According to the results, at the beginning years of university, it is suggested to make prevention and quitting programs which includes secondhand smoke exposure.

Keywords: Environmental tobacco smoke, secondhand smoke, smoking, tobacco
Received/Geliş: 20.09 .2018

Accepted/Kabul: 30.12.2019

Published Online: 23.12.2020

Cite as: Kaya M, Ergün A. Sağlık bilimleri öğrencilerinin sigara içme durumu, etkileyen faktörler ve ikincil sigara dumanı ile ilgili farkındalık düzeyleri. Jaren. 2020;6(3):416-25.

Merve Kaya Marmara Üniversitesi Sağlık Bilimleri Fakültesi, Halk Sağlığı Hemşireliği Anabilim Dalı, İstanbul - Türkiye mervepetek34@gmail.com ORCID: 0000-0001-9289-4942

A. Ergün 0000-0003-3132-2005 Marmara Üniversitesi Sağlık Bilimleri Fakültesi, Halk Sağlığı Hemşireliği Anabilim Dalı, Istanbul, Türkiye 


\section{Giriş}

Sigara, en çok tüketilen tütün ürünü ve en iyi bilinen kanser nedenidir. İçeriğindeki birçok madde ile birçok hastalık özellikle de kanser türleri için başlıca çevresel neden olarak bilinir ve tüm dünyada önemli bir halk sağlığı sorunudur ${ }^{(1-5)}$.

Kendinden başka birinin içtiği sigara dumanının solunmasına pasif içicilik denir. Literatürde ikincil sigara dumanı maruziyeti ya da çevresel tütün dumanı maruziyeti olarak da geçer. İkincil sigara dumanı birçok bileşiğin kompleks yapısından oluşur ve biyolojik belirteçler ile vücutta belirlenebilir ${ }^{(6)}$. Tütün ürünlerinin tüketildiği kapalı ortamlarda çevresel tütün dumanı maruziyeti vardır.

Sigara içmek kardiovasküler sistem hastalıkları, cinsel işilev bozuklukları, gebelik ve yenidoğan sürecini olumsuz etkileyecek durumlar, bağışıklık sistemi hastalıkları, kanser, ruh sağlığı hastalıkları, ağız ve diş sağlığı hastalıkları, günlük yaşam kalitesinde düşüklük, böbrek fonksiyonlarında bozulmalar, akciğer hastalıkları, diyabet gibi hastalıklara yol açmaktadır $(1,3,7-9)$. İincil sigara dumanı ise akut olarak gözlerde yanma, kaşınma, kızarıklık, mukoza iritasyonu, baş ve boğaz ağrısı, öksürük gibi belirtiler gösterebilir. Uzun süren maruziyet kanserojenik etki, gebelikte anne ve bebeğin zarar görmesi, ruh sağlığı sorunları, akciğer hastalıkları, kardiovasküler hastalıklara yol açabilir (10-12).

Dünyada 15 yaş üzeri sigara içen 1 milyar insan bulunmaktadır. Bu, dünya nüfusunun yaklaşık olarak \%24'ünü oluşturmaktadır ${ }^{(13)}$. Sigara içme sıklığı en fazla Avrupa'dadır. Avrupa'yı Batı Pasifik, Amerika, Güneydoğu Asya, Doğu Akdeniz ve Afrika izlemektedir. Dünya genelinde erkeklerin sigara içme sıklığının kadınlardan daha fazla olduğu görülmüştür ${ }^{(14)}$. Her yıl 400 binden fazla bireyin sigara kaynaklı nedenlerle yaşamını kaybettiği görülmektedir. Sigara içme sıklığı en yüksek 25-44 yaş, en düşük 65 yaş üzerindedir ${ }^{(15)}$.

Küresel Yetişkin Tütün Araştırması (KYTA) 2012 sonuçlarına göre Türkiye, en fazla tütün ürünü kullanan altıncı ülkedir. Türkiye'de 15-24 yaş arasındaki erkeklerin $\% 41.5^{\prime} \mathrm{i}$, kadınların $\% 13.1^{\prime} \mathrm{i}, 15-24$ yaş arasındaki genel nüfusun \%27.1'inin güncel olarak sigara içtiği belirlenmiştir ${ }^{(4)}$. KYTA 2008 ve 2012 sonuçlarına göre ülkemizde iki cinsiyette de sigara içme prevalansının azaldığı belirlenmiştir. Sigara bırakma düşüncesi, düzenli sigara içenlerde artmaktadır ${ }^{(16)}$.

Dünyada yapılan araştırmalara göre, 25 yaş üstü bireyler yüksek oranlarda ikincil sigara dumanına maruz kalmakta ve yaşla beraber maruziyet artmaktadır ${ }^{(17)}$. Avrupa Birliği ülkelerinde yapılan araştırmada sigara içmeyip ikincil sigara dumanına maruz kalma sıklığının \%13.6 olduğu görülmüştür ${ }^{(18)}$. KYTA Türkiye 2012 sonuçlarına göre 15-24 yaşta ikincil sigara dumanına en fazla kafelerde (\%30.4) maruz kaldığı, bunu sırasıyla okullar (\%18.2), toplu taşıma (\%12.5), resmi kurumlar (\%8) ve sağlık kuruluşları (\%4.2) izlemektedir ${ }^{(4)}$.

Çalışmalarda sağlık profesyonellerinin sigara içme prevalansının \%12-37.2 arasında değiştiği ve oldukça yüksek olduğu belirtilmektedir ${ }^{(19-21)}$. Sağlık profesyonelleri sigara içme ve ikincil sigara dumanı konusunda topluma rol model olması, danışmanlık vermesi ve toplumsal programlarda önderlik yapması beklenen bir gruptur. Sağlık profesyonellerinin sigara içme prevalansını etkileyen faktörler ve ikincil sigara dumanı maruziyeti ile ilgili farkındalıklarının bilinmesi, sigara önleme çalışmaları için gereklidir.

Bu çalışma; geleceğin sağlık profesyoneli olacak sağılı bilimleri öğrencilerinin sigara içme durumları, etkileyen faktörler ve ikincil sigara dumanı ile ilgili farkındalık düzeylerini belirlemek amacıyla yapıldı. Öğrencilerin sigara içme sıklığı, sigara içme durumIarını etkileyen faktörler, sigara bağımlığı düzeyleri ve ikincil sigara dumanı maruziyeti düzeyleri sorgulandı.

\section{YÖNTEM}

\section{Araştırmanın Türü}

Araştırma tanımlayıcı türde yapıldı.

\section{Araştırmanın Evreni ve Örneklemi}

Araştırma İstanbul'da bir devlet üniversitesinin sağlık bilimleri fakültesi öğrencileri ile (N=1054) Kasım 2016'da yapıldı. Örneklem seçimi yapılmayıp, çalışmaya katılmaya gönüllü 1054 öğrenci ile çalışma tamamlandı (Katılım oranı: \%44.47). Gönüllü olan tüm öğrenciler araştırmaya dahil edilirken, katılmak 
istemeyen öğrenciler dahil edilmedi.

\section{Veri Toplama Araçları ve Verilerin Toplanması}

Veriler üniversitenin dersliklerinde özbildirime dayalı olarak; sosyodemografik form, ikincil sigara dumanı ve sigara içiciliği ile ilgili anket formu ve Fagerström Nikotin Bağımlılık Testi kullanılarak çoktan seçmeli ve likert tipli karışık sorular ile toplandı.

Sosyodemografik Form: Bu formda araştırmacı tarafından literatür bilgileri taranarak oluşturulan öğrencinin bölümü, sınıfı, yaşı, cinsiyeti, gelir durumunu nasıl değerlendirdiği, aile tipi, kiminle yaşadığı, anne ve babasının eğitim durumu, kendisinin çalışma durumu ve kronik hastalık durumunu içeren 11 soru yer almaktadır.

İkincil Sigara Dumanı ve Sigara İçiciliği ile Illgili Anket Formu: İkincil Sigara Dumanı ve Sigara İçiciliği Ile İlgili Anket Formu, Araştırmacı tarafından Dünya Sağı̆ık Örgütü (DSÖ) ve Hastalık Kontrol ve Korunma Merkezi (CDC) tarafından yapılan çalışmada kullanılan Küresel Yetişkin Tütün Anketi (KYTA) temel alınarak, ilgili literatür bilgileri taranarak ve sigara ile ilgili etkili faktörler değerlendirilerek oluşturuldu ${ }^{(2,4,13)}$. İkincil sigara dumanı maruziyeti varlığını, farkındalık durumunu ve hangi ortamlarda daha çok maruz kalındığını belirlemek amacıyla 17 soru soruldu. Sigara içme durumu, etkileyen faktörler ve bırakma düşüncesi ile ilgili 11 soru soruldu ve bu soruları sadece sigara içen öğrenciler yanıtladı. Öğrencilerin sigara bırakma ile ilgili niyeti Transteoretik Model Değişim Aşamaları'na göre 3 seçenekte değerlendirildi. Gelecek 6 ay içindesigarayı bırakmayı düşünmeyenler "düşünmeme", gelecek 6 ay içindesigara bırakmayı düşünenler "düşünme" ve gelecek 30 gün içindesigara bırakmayı düşünenler "hazırlık" aşamasında kabul edildi.

Fagerstrom Nikotin Bağımlılık Testi: Bireylerin nikotin bağımlılık düzeyini girişimsel olmayan yöntemle gösteren bu ölçek Fagerstrom tarafından 1989 yılında geliştirildi. Ölçek 6 sorudan oluşmaktadır ve ölçekten toplam puanı en az 0 , en yüksek 10 puandır (22). Uysal tarafından 2004 yılında Türkçe'ye uyarlanmış ve alpha güvenirlik katsayısı 0.56 olarak bulunmuştur. Bu çalışmada, alpha güvenirlik katsayısı 0.63 bulundu. Yalnızca sigara içen öğrencilerin bu soruları yanıtlaması istendi.

\section{Prosedür}

Çalışma bir devlet üniversitesinde yapıldı. Anket formları ders saati başlamadan $15 \mathrm{dk}$. önce sınıf ortamındaki öğrencilere dağıtıldı ve yaklaşık $15 \mathrm{dk}$. içerisinde yanıtlandıktan sonra geri toplandı.

\section{Araştırmanın Sınırılııları}

Bu çalışmanın sınırlıı̆̆ı ikincil sigara dumanına maruziyet süresinin sorgulanmaması/ölçülmemesidir. Sonraki çalışmalarda bu faktörün de sorgulanması önerilir.

\section{Araştırmanın Etik Boyutu}

Fagerstrom Nikotin Bağımlılık Testi'nin çalışmada kullanım izni Uysal'dan alındı. Araştırmaya başlamadan önce üniversitenin Sağlık Bilimleri Enstitüsü Etik Kurulu'ndan etik izin, Sağlık Bilimleri Fakültesi Dekanlığı'ndan kurum izni ve öğrencilerden yazılı onam alındı.

\section{İstatistiksel Analiz}

Verilerin analizi Statistical Package for the Social Science (SPSS, Version 20) programında, tanımlayıcı istatistikler ve kikare analizi ile yapıldı.

\section{BULGULAR}

Araştırmaya katılan öğrencilerin yaşları 17-32 arasında değişmekte olup, yaş ortalaması 20.06 \pm 1.66 idi. Öğrencilerin \%84.5'i kız, \%15.5'i erkekti. Öğrencilerin $\% 51.6$ 'sı hemşirelik bölümü öğrencisi ve $\% 31^{\prime} i$ üçüncü sınıftaydı. Yüzde 77.9'u çekirdek aileye, \%83.9'u orta gelir düzeyine sahip, $\% 44.5^{\prime} i$ yurtta yaşıyordu. Anne-baba eğitim durumu çoğunlukla ilkokuldu. Öğrencilerin \%7.6'sı ücretli bir işte çalışıyordu, \%5.7'sinin kronik bir hastalığı vardı (Tablo 1).

Öğrencilerin \%13.9'u sigara içtiğini, \%22.7'si ise herhangi bir nedenle sigarayı denediğini bildirdi. Günlük içilen sigara miktarı ortalaması $10.77 \pm 9.34$ 'tü. Sigarayı ilk deneme yaşının 5-23 arasında değiştiği ve deneme nedeninin \%45.9'unda merak, \%35'inde arkadaş özendirmesi olduğu belirlendi. Yüzde 56.6 'sının ailesinde sigara içen birey vardı ve \%46.9'u stresli iken, \%27.2'si etrafında sigara içen birileri varken daha çok sigara içtiğini söyledi. Fagerström Nikotin Bağımlılık Testi'ne göre öğrencilerin \%51.3'ü orta düzeyde, \%26.9'u yüksek düzeyde bağımlı bulundu. Kendi düşüncelerine göre değerlendirildi- 
Tablo 1. Öğrencilerin Cinsiyete Göre Sosyodemografik Özellikleri

\begin{tabular}{|c|c|c|c|}
\hline \multicolumn{2}{|l|}{ Değiş̧enler } & $\mathbf{n}$ & $\%$ \\
\hline \multicolumn{4}{|c|}{ Yaş (Ort=20.06 \pm 1.66 min=17 max=32) } \\
\hline & Beslenme ve Dyt. & 102 & 9.7 \\
\hline & Ebelik & 136 & 12.9 \\
\hline \multirow[t]{3}{*}{ Bölüm } & Fizik Tedavi ve Reh. & 169 & 16 \\
\hline & Hemşirelik & 544 & 51.6 \\
\hline & Sağlık Yönetimi & 103 & 9.8 \\
\hline \multirow[t]{2}{*}{ Sinıf } & 1 ve 2 . Sinif & 568 & 53.9 \\
\hline & 3 ve 4 . Sinıf & 486 & 46.1 \\
\hline \multirow[t]{3}{*}{ Gelir Düzeyi } & Düşük & 139 & 13.2 \\
\hline & Orta - Yüksek & 915 & 86.8 \\
\hline & Çekirdek & 821 & 77.9 \\
\hline \multirow[t]{3}{*}{ Aile Tipi } & Geniş & 204 & 19.4 \\
\hline & Anne-Baba Boşanmış & 29 & 2.8 \\
\hline & Ailesi İle Birlikte & 447 & 42.4 \\
\hline \multirow[t]{4}{*}{ Yaşanılan Yer } & Kendi/Arkadaşları ile Evde & 138 & 13.1 \\
\hline & Yurtta & 469 & 44.5 \\
\hline & Okuryazar Değil & 125 & 11.9 \\
\hline & İlkokul & 534 & 50.7 \\
\hline \multirow{5}{*}{ Anne Eğitim Durumu } & Ortaokul & 168 & 15.9 \\
\hline & Lise & 167 & 15.8 \\
\hline & Üniversite ve Üzeri & 60 & 5.7 \\
\hline & Okuryazar Değil & 25 & 2.4 \\
\hline & ilkokul & 384 & 36.4 \\
\hline \multirow[t]{3}{*}{ Baba Eğitim Durumu } & Ortaokul & 238 & 22.6 \\
\hline & Lise & 252 & 23.9 \\
\hline & Üniversite ve Üzeri & 155 & 14.7 \\
\hline \multirow[t]{2}{*}{ Çalışma Durumu } & Çalışmıyor & 974 & 92.4 \\
\hline & Çalışıyor & 80 & 7.6 \\
\hline \multirow[t]{2}{*}{ Kronik Hastalık } & Hayır, Yok & 994 & 94.3 \\
\hline & Evet, Var & 60 & 5.7 \\
\hline \multicolumn{2}{|l|}{ Toplam } & 1054 & 100 \\
\hline
\end{tabular}

ğinde ise sigara içen öğrencilerin $\% 58.4$ 'ü sigaraya bağımlı olduğunu düşünmemekteydi (Tablo 2).

Son 30 gün içinde öğrencilerin $\% 96,9^{\prime} u$ ikincil sigara dumanına maruz kaldığını bildirdi. En yüksek maruziyet kafe-restoranlarda (\%52.4) olmakla birlikte, okul (\%26.9) ve evde (\%24.2) de maruziyet vardı. Öğrencilerin \%55.4'ünün ailesinin yaşadığı evde sigara içiliyordu. Öğrencilerin \%7.4'ü ikincil sigara dumanının zararlı olduğunu düşünmüyor ve $\% 34.5^{\prime} \mathrm{i}$ son 30 gün içinde kitle iletişim araçlarında sigara ve zararları ile ilgili bilgi fark etmemiş olduğunu belirtti (Tablo 3).

Öğrencilerin sigara bırakmaileilgiliniyeti Transteoretik Model Değişim Aşamaları'na göre değerlendirildiğin-
Tablo 2. Öğrencilerin Sigara İçme Durumu ile ilgili Özellikleri $(\mathrm{N}=1054)$

\begin{tabular}{|c|c|c|c|}
\hline \multicolumn{2}{|l|}{ Değişkenler } & $\mathbf{n}$ & $\%$ \\
\hline Güncel Sigara İçme & Sigara İçmeye Devam Edenler & 147 & 13.9 \\
\hline \multirow[t]{3}{*}{ Durumu } & Sigara İçmeyenler & 907 & 86.1 \\
\hline & Her Gün & 85 & 8.1 \\
\hline & Her Gün Değil / Ara Sıra & 62 & 5.9 \\
\hline \multirow{3}{*}{$\begin{array}{l}\text { Sigara İçme/Deneme } \\
\text { Durumu }\end{array}$} & Denedim ama Devam Etmedim & 239 & 22.7 \\
\hline & Hiç Sigara İçmedim & 655 & 62.1 \\
\hline & Belirli Bir Süre İçip Bıraktım & 13 & 1.2 \\
\hline \multirow[t]{2}{*}{ Ailede Sigara İçen Birey } & Yok & 457 & 43.4 \\
\hline & Var & 597 & 56.6 \\
\hline Sigara içen kişi & Anne & 161 & 15.3 \\
\hline *Duygusal arkadaş & Baba & 395 & 37.5 \\
\hline seçeneğinde yüzdeler & Kardeş & 241 & 22.9 \\
\hline duygusal arkadaşı olan & Yakın arkadaş & 589 & 55.9 \\
\hline öğrenciler üzerinden alındı. & Duygusal arkadaş & 120 & $33.1 *$ \\
\hline \multirow{3}{*}{$\begin{array}{l}\text { Günlük Içcilen Sigara Miktarı } \\
(\mathrm{n}=116)(\text { Ort }=10,77 \pm 9,34 \\
\min =0, \max =60)\end{array}$} & $0-10$ & 73 & 62.9 \\
\hline & $11-20$ & 33 & 28.4 \\
\hline & 21 ve Daha Fazla & 10 & 8.6 \\
\hline \multirow{3}{*}{$\begin{array}{l}\text { Sigara Deneme Yaşı }(\mathrm{n}=161) \\
\text { (Ort }=15.88 \pm 3.44 \\
\min =5, \max =23)\end{array}$} & $5-11$ & 15 & 9.3 \\
\hline & $12-16$ & 62 & 38.5 \\
\hline & $17-23$ & 84 & 52.2 \\
\hline \multirow{3}{*}{$\begin{array}{l}\text { Her Gün Sigara İçmeye } \\
\text { Başlama Yaşı } \\
(n=92) \quad(O r t=17.61 \pm 2.59 \\
\min =7, \max =24)\end{array}$} & 7-16 Üniversite Öncesi & 23 & 25.0 \\
\hline & 17-24 Üniversite Sonrası & 69 & 75.0 \\
\hline & & & \\
\hline \multirow{7}{*}{$\begin{array}{l}\text { Sigarayı İlk Deneme } \\
\text { Nedeni }\end{array}$} & Merak & 72 & 45.9 \\
\hline & Özenti & 12 & 7.6 \\
\hline & Arkadaş Teşviki & 55 & 35.0 \\
\hline & Yakınının Teşviki & 10 & 6.9 \\
\hline & Üzüntü & 4 & 2.6 \\
\hline & Stres & 12 & 7.7 \\
\hline & Kişisel İstek & 13 & 8.4 \\
\hline \multirow{8}{*}{$\begin{array}{l}\text { Hangi Durumlarda Daha } \\
\text { Çok Sigara İciyorsunuz? } \\
\text { ( } n=147)\end{array}$} & Hiç Düşünmedim & 23 & 15.6 \\
\hline & Stresliyken & 69 & 46.9 \\
\hline & Heyecanlıyken & 13 & 8.8 \\
\hline & Herhangi bir Sebep Olmadan & 30 & 20.4 \\
\hline & Yalnızken & 26 & 17.7 \\
\hline & Etrafta Sigara İçen Birileri & 40 & 27.2 \\
\hline & Varken & & \\
\hline & Kalabalık Bir Gruptayken & 34 & 23.3 \\
\hline \multirow{5}{*}{$\begin{array}{l}\text { Fagerström Nikotin } \\
\text { Bağımlılık Testi'ne Göre } \\
\text { Bağımlılık Durumları } \\
\text { (Ort=5.48 } 1.96 \\
\min =1, \max =9 \text { ) }\end{array}$} & Çok Düşük & 0 & 0 \\
\hline & Düşük & 11 & 9.2 \\
\hline & Orta & 61 & 51.3 \\
\hline & Yüksek & 32 & 26.9 \\
\hline & Ağır (8-10 Puan) & 15 & 12.6 \\
\hline \multirow{3}{*}{$\begin{array}{l}\text { Öğrencilerin Kendi } \\
\text { Düşüncelerine Göre } \\
\text { Bağımlılık Durumları }\end{array}$} & Bağımlı Olduğunu Düşünen & 52 & 41.6 \\
\hline & Bağımlı Olduğunu Düşünmeyen & 73 & 58.4 \\
\hline & & & \\
\hline
\end{tabular}

de \%49.3'ü düşünmeme, \%27.1'i düşünme ve \%23.6'sı hazırlık aşamasındaydı. Öğrencilerin \%36.4'ü okulda bir sigara bırakma programı olsa katılmak 
Tablo 3. Öğrencilerin ikincil Sigara Dumanı Maruziyeti ile ilgili Özellikleri

\begin{tabular}{|c|c|c|c|}
\hline \multicolumn{2}{|l|}{ Değişkenler } & \multirow{2}{*}{$\frac{n}{33}$} & \multirow{2}{*}{$\begin{array}{c}\% \\
3.1\end{array}$} \\
\hline Son 30 Gün İçinde İkincil & Hiç Maruz Kalmamış & & \\
\hline \multirow[t]{4}{*}{ Sigara Dumanı Maruziyeti } & Maruz Kalmış & 1021 & 96.9 \\
\hline & Ev & 255 & 24.2 \\
\hline & Okul & 284 & 26.9 \\
\hline & İşyeri & 56 & 5.3 \\
\hline Son 30 Gün İçinde İkincil & Kafe-Restoran & 552 & 52.4 \\
\hline Sigara Dumanına Maruz & Yurt & 51 & 4.8 \\
\hline \multirow[t]{3}{*}{ Kalınan Yer } & Otobüs ve Duraklar & 100 & 9.5 \\
\hline & Açık Hava & 61 & 5.8 \\
\hline & Hastane-Staj & 11 & 1 \\
\hline \multirow{5}{*}{$\begin{array}{l}\text { Yaşadığı Yerde İkincil Sigara } \\
\text { Dumanına Maruz Kalma Sıklığı }\end{array}$} & Hiçbir Zaman & 125 & 11.9 \\
\hline & Nadiren & 325 & 30.8 \\
\hline & Bazen & 368 & 34.9 \\
\hline & Çoğunlukla & 187 & 17.7 \\
\hline & Her Zaman & 49 & 4.6 \\
\hline \multirow{2}{*}{$\begin{array}{l}\text { Ailenin Yaşadığı Evde Sigara } \\
\text { İçen Birey }\end{array}$} & Var & 470 & 44.6 \\
\hline & Yok & 584 & 55.4 \\
\hline \multirow{3}{*}{$\begin{array}{l}\text { Ailenin Yaşadığı Evde Sigara } \\
\text { İçen Kişi }\end{array}$} & Anne & 106 & 10.1 \\
\hline & Baba & 295 & 28 \\
\hline & Kardeş & 140 & 13.3 \\
\hline Okulda İkincil Sigara & Hiçbir Zaman & 237 & 22.5 \\
\hline \multirow[t]{4}{*}{ Dumanına Maruz Kalma Sıklığı } & Nadiren & 418 & 39.7 \\
\hline & Bazen & 299 & 28.4 \\
\hline & Çoğunlukla & 74 & 7 \\
\hline & Her Zaman & 26 & 2.5 \\
\hline İşyerinde İkincil Sigara & Hiçbir Zaman & 17 & 21.25 \\
\hline Dumanına Maruz Kalma & Nadiren & 22 & 27.5 \\
\hline Sıklığı $(n=80)^{*}$ & Bazen & 19 & 23.75 \\
\hline \multirow{2}{*}{$\begin{array}{l}\text { *:Yüzdeler çalışanlar } \\
\text { üzerinden alındı. }\end{array}$} & Çoğunlukla & 15 & 18.75 \\
\hline & Her Zaman & 7 & 8.75 \\
\hline Son 30 Günde Devlet & Ziyaret etmedim & 200 & 19 \\
\hline Kurumunda Kapalı Alanda & Evet, gördüm & 74 & 7 \\
\hline Sigara İçen Birey Gördünüz mü? & Hayır, görmedim & 780 & 74 \\
\hline \multirow{3}{*}{$\begin{array}{l}\text { Son } 30 \text { Günde Sağlık } \\
\text { Kurumunda Kapalı Alanda } \\
\text { Sigara İçen Birey Gördünüz mü? }\end{array}$} & Ziyaret etmedim & 144 & 13.7 \\
\hline & Evet, gördüm & 121 & 11.5 \\
\hline & Hayır, görmedim & 789 & 74.9 \\
\hline Açık Alanda Başkasının İçtiği & Evet & 859 & 81.5 \\
\hline $\begin{array}{l}\text { Sigara Dumanı Rahatsız Eder } \\
\text { mi? }\end{array}$ & Hayır & 195 & 18.5 \\
\hline \multirow{3}{*}{$\begin{array}{l}\text { Sizce başka birinin kullandığı } \\
\text { tütün ürününün dumanı size } \\
\text { zarar verir mi? }\end{array}$} & Evet & 976 & 92.6 \\
\hline & Hayır & 41 & 3.9 \\
\hline & Emin değilim & 37 & 3.5 \\
\hline \multirow{6}{*}{$\begin{array}{l}\text { Son } 30 \text { gün içinde } \\
\text { aşağıdakilerden birinde } \\
\text { sigaranın zararları veya sigara } \\
\text { bırakma ile ilgili herhangi bir } \\
\text { bilgi fark ettiniz mi? }\end{array}$} & Fark etmedim & 364 & 34.5 \\
\hline & Gazete ve Dergi & 74 & 7 \\
\hline & Televizyon & 496 & 47.1 \\
\hline & Radyo & 21 & 2 \\
\hline & İlan Panoları & 100 & 9.5 \\
\hline & İnternet & 182 & 17.3 \\
\hline
\end{tabular}

istediğini belirtti. Sigara içen öğrencilerden daha önce sigara bırakmayı denemiş, ancak başarısız olanların oranı \%29.3'tü (Tablo 4).
Tablo 4. Öğrencilerin Sigara Bırakma ile ilgili Özellikleri ( $n=140)$

\begin{tabular}{|c|c|c|c|}
\hline \multicolumn{2}{|l|}{ Değişkenler } & $\mathbf{n}$ & $\%$ \\
\hline Sigara Bırakmayı Ciddi & Evet (Gelecek 30 Gün İçinde) & 33 & 23.6 \\
\hline Olarak Düşünüyor & Evet (Gelecek 6 Ay İçinde) & 38 & 27.1 \\
\hline Musunuz? & $\begin{array}{l}\text { Hayır (Bırakmayı Hiç } \\
\text { Düsünmedim }\end{array}$ & 69 & 49.3 \\
\hline \multirow{2}{*}{$\begin{array}{l}\text { Önceden Sigara Bırakmayı } \\
\text { Denediniz mi? }\end{array}$} & Evet & 41 & 29.3 \\
\hline & Hayır & 99 & 70.7 \\
\hline \multirow{5}{*}{$\begin{array}{l}\text { Sigara Bırakmaya } \\
\text { Özendirici Faktörler }\end{array}$} & Sigara Fiyatları & 68 & 48.6 \\
\hline & Sağlık Sorunları & 78 & 55.7 \\
\hline & Çevre Baskısı & 22 & 15.7 \\
\hline & Sigara İçecek Yer Bulma & 11 & 7.9 \\
\hline & Kampanyalar & 8 & 5.7 \\
\hline \multirow{2}{*}{$\begin{array}{l}\text { Okulda sigara bırakma } \\
\text { programı yapılırsa } \\
\text { yararlanmak ister misiniz? }\end{array}$} & Evet & 51 & 36.4 \\
\hline & Hayır & 89 & 63.6 \\
\hline
\end{tabular}

Cinsiyet, gelir düzeyi, yaşanılan yer ve çalışma durumu ile sigara içme arasında istatistiksel olarak anlamIı fark bulundu. Erkek, düşük gelir düzeyine sahip, öğrenci evinde kalan ve çalışan öğrencilerin sigara içme oranları diğerlerine göre daha yüksekti. Kronik hastalık ile sigara içme durumu karşılaştırıldığında istatistiksel olarak anlamlı bir fark bulunmadı. Yapılan analizler sonucu kronik hastalığı olan 10 öğrencinin sigara içtiği görüldü. Kronik astımı olan 22 öğrenciden 4 'ü sigara içtiğini ve $5^{\prime} i$ evinde, 6 'sı okulda ikincil sigara dumanına maruz kaldığını belirtti (Tablo 5).

\section{TARTIŞMA}

Bu çalışmada, öğrencilerin \%13.9'unun her gün ya da ara sıra sigara içmekte olduğu belirlendi. Ülkemizde yapılan benzer çalışmalarda, sigara içme sıklığının 2011 yılında \%40.3'e kadar yükseldiği görülmekle birlikte, son yıllarda benzer sonuçlar elde edilmiştir (2, 23-26). Dünyada ise sigara içme prevalansının \%9.456.4 aralığında ve çoğunun \%20'nin üzerinde olduğu görülmektedir ${ }^{(5,27-29)}$. Sağlık profesyonelleri ile yapılan araştırmalarda, sigara içme prevalansının \%29.640.3 aralığında değişmekte olduğu belirlenmiştir $(20,30)$.

Literatürde sigara deneme oranları \%39.5-70.9 arasında değişmektedir ${ }^{(19,24,31)}$. Bu çalışmada, sigara deneme oranının nispeten daha düşük (\%37.9) olduğu görülmekle birlikte, yine de yüksek bir orana sahiptir. Sigara içen öğrencilerin çoğunun aile bireyleri ve yakın arkadaşlarının sigara içtiği ve sigarayı ilk 
Tablo 5. Öğrencilerin Sosyodemografik Özelliklerine Göre Sigara İ̧̧me Durumlarının Karşılaştırılması

\begin{tabular}{|c|c|c|c|c|c|c|}
\hline \multirow[b]{2}{*}{ Değişkenler } & \multicolumn{2}{|c|}{ Sigara İçen } & \multicolumn{2}{|c|}{ Sigara İçmeyen } & \multicolumn{2}{|c|}{ İstatistik } \\
\hline & $\mathbf{n}$ & $\%$ & $\mathrm{n}$ & $\%$ & $x^{2}$ & $\mathbf{p}$ \\
\hline \multicolumn{7}{|l|}{ Bölüm } \\
\hline Beslenme ve Diyetetik & 9 & 8.8 & 93 & 91.2 & 10.85 & .028 \\
\hline Ebelik & 15 & 11.0 & 121 & 89.0 & & \\
\hline Fizik Tedavi ve Rehabilitasyon & 25 & 14.8 & 144 & 85.2 & & \\
\hline Hemşirelik & 74 & 13.6 & 470 & 86.4 & & \\
\hline Sağlık Yönetimi & 24 & 23.3 & 79 & 76.7 & & \\
\hline \multicolumn{7}{|l|}{ Sinıf } \\
\hline 1 ve 2 . Sinıf & 70 & 12.3 & 498 & 87.7 & 2.70 & .109 \\
\hline 3 ve 4 . Sinif & 77 & 15.8 & 409 & 84.2 & & \\
\hline \multicolumn{7}{|l|}{ Cinsiyet } \\
\hline $\mathrm{K} \mathrm{Iz}$ & 96 & 10.8 & 795 & 89.2 & 48.31 & .000 \\
\hline Erkek & 51 & 31.3 & 112 & 68.7 & & \\
\hline \multicolumn{7}{|l|}{ Gelir Düzeyi } \\
\hline Düşük & 32 & 23.0 & 107 & 77.0 & 10.98 & .002 \\
\hline Orta - Yüksek & 115 & 12.6 & 800 & 87.4 & & \\
\hline \multicolumn{7}{|l|}{ Aile Tipi } \\
\hline Çekirdek & 114 & 13.9 & 707 & 86.1 & 7.86 & .020 \\
\hline Geniş & 24 & 11.8 & 180 & 88.2 & & \\
\hline Anne-Baba Boşanmış & 9 & 31.0 & 20 & 69.0 & & \\
\hline \multicolumn{7}{|l|}{ Yaşanılan Yer } \\
\hline Ailesi ile Birlikte & 43 & 9.6 & 404 & 90.4 & 24.03 & .000 \\
\hline Yalnız/Arkadaşları ile Evde & 36 & 26.1 & 102 & 73.9 & & \\
\hline Yurtta & 68 & 14.5 & 401 & 85.5 & & \\
\hline \multicolumn{7}{|l|}{ Anne Eğitim Durumu } \\
\hline Okuryazar Değil & 17 & 13.6 & 108 & 86.4 & 4.23 & .375 \\
\hline İlkokul & 66 & 12.4 & 468 & 87.6 & & \\
\hline Ortaokul & 25 & 14.9 & 143 & 85.1 & & \\
\hline Lise & 31 & 18.6 & 136 & 81.4 & & \\
\hline Üniversite ve Üzeri & 8 & 13.3 & 52 & 86.7 & & \\
\hline \multicolumn{7}{|l|}{ Baba Eğitim Durumu } \\
\hline Okuryazar Değil & 3 & 12.0 & 22 & 88.0 & 8.30 & .081 \\
\hline İlkokul & 42 & 10.9 & 342 & 89.1 & & \\
\hline Ortaokul & 30 & 12.6 & 208 & 87.4 & & \\
\hline Lise & 43 & 17.1 & 209 & 82.9 & & \\
\hline Üniversite ve Üzeri & 29 & 18.7 & 126 & 81.3 & & \\
\hline \multicolumn{7}{|l|}{ Çalışma Durumu } \\
\hline Çalışmıyor & 121 & 12.4 & 853 & 87.6 & 24.82 & .000 \\
\hline Çalışıyor & 26 & 32.5 & 54 & 67.5 & & \\
\hline \multicolumn{7}{|l|}{ Kronik Hastalık } \\
\hline Hayır, Yok & 137 & 13.8 & 857 & 86.2 & 0.39 & .563 \\
\hline Evet, Var & 10 & 16.7 & 50 & 83.3 & & \\
\hline Astim $(n=22)$ & 4 & 18.2 & 18 & 81.8 & 0.33 & .533 \\
\hline Astımlı Öğrencilerin ( $n=22$ ) ikincil Sigara Dumanı Maruziyeti & \multicolumn{2}{|c|}{ Maruz Kalan } & \multicolumn{2}{|c|}{ Maruz Kalan } & & \\
\hline Evde & 5 & 22.7 & 17 & 87.3 & 0.02 & 1.000 \\
\hline Okulda & 6 & 27.3 & 16 & 82.7 & 0.00 & 1.000 \\
\hline
\end{tabular}

deneme nedenlerinin merak ve arkadaş özendirmesi olduğu sonucu ülkemizde ve dünyadaki çalışmalarla paralellik göstermektedir (8,19,23,24,27,32-34). Öğrenciler için stresin sigara alışkanlıklarını desteklediği ve kalabalık arkadaş ortamlarında daha çok sigara içtikleri bu çalışma ve literatürdeki benzer çalışmalarda görülmektedir ${ }^{(23,35,36)}$.

Bu çalışmada, sigarayı ilk kez deneme yaşının literatüre benzer olarak 5-9 yaşa kadar indiği belirlenmiştir ${ }^{(37)}$. Her gün sigara içmeye başlama yaşı ise lise son sınıf ya da üniversite ilk yıllarına denk gelen
17-23 yaş aralığında yoğunlaşmaktadır. Literatürde sigaraya başlama yaşı çoğunlukla 15-16 yaş olarak belirtilmektedir ${ }^{(19,23,24,27,35,38)}$. Bu sonuçlar, sigara önleme eğitimlerinin erken adölesan dönemde yapılması gerektiğini göstermektedir.

Bu çalışmada, öğrencilerin \%96.9'u son 30 gün içinde ikincil sigara dumanına maruz kaldığını söyledi. Ülkemizde 2008 yılından itibaren kapalı alanlarda sigara içme yasağı olmasına rağmen, öğrencilerin önemli bir bölümü okulda, evde, kafe ve restoranlarda ikincil sigara dumanına maruz kaldığını belirtmiş- 
tir. Literatürde ikincil sigara dumanı maruziyetinin yüksek olduğu belirtilmektedir (6,16,17,35,39). Okulda ikincil sigara dumanı maruziyetini öğrencilerin çoğu "Nadiren" olarak yanıtladı. Ülkemizde ve dünyada yapılan benzer araştırmalarda öğrencilerin ve bu yaş grubu bireylerin genel olarak yarısından fazlasının okulların değişik alanlarında ikincil sigara dumanına maruz kaldığı görülmektedir ${ }^{(16,25,32,39)}$.

Bu çalışmada, öğrencilerin \%24.2'si evde ikincil sigara dumanına maruz kaldığını belirtti. Bireylerin yaşadığı evde ikincil sigara dumanına maruz kalması, diğer kapalı mekanlardaki maruziyetten daha zararlıdır. Hem süre olarak bakıldığında evde geçirilen zaman diğerlerine oranla daha fazladır hem de sigara içilen evlerde üçüncül sigara dumanı maruziyeti varlığı söz konusudur. Sigara içilen bir evde zararlı partiküller havalandırmakla evlerden uzaklaştıılamayabilir. Duvarlara, döşemelere, evdeki eşyalara hapsolan bu partiküller, sigara içildiği anda evde olmayıp sonradan gelen bireylerin de sigara dumanına üçüncül olarak maruz kalmalarına neden olmaktadır (www. cancer.org Erişim Tarihi: 12.01.2017).

Bu çalışmada, işyerlerinde ikincil sigara dumanı maruziyetinin \%5.3 olması, çalışan öğrenci sayısının az olması ve kapalı alanda sigara içme yasağıyla ilgili olabilir. Buna rağmen, ücretli bir işte çalışan öğrencilerin büyük çoğunluğunun (\%78.75), nadiren de olsa, işyerlerinde ikincil sigara dumanına maruz kaldığı görülmektedir. Bazı iş yerlerinde sigara içme için yapılan özel alanlar, tüm personelin kullandığı ortak alanlardır. Ortak alanlarda sigara içilmesi, sigara içmeyen bireyler için ikincil sigara dumanı maruziyeti ile ilgili yüksek risk oluşturmaktadır.

Öğrencilerin \%7.4'ü ikincil sigara dumanının kendisi için zararlı olduğunu düşünmüyor veya zararından emin değildi. Diğer çalışmalarda zararlı olmadığını düşünen öğrenciler \%3.6-14.5 aralığındaydı (16,23,24,35,4042). Sigara içmeyen öğrencilerin $\% 1.5^{\prime} \mathrm{i}$, içen öğrencilerin \%18.4'ü ikincil sigara dumanının kendisine zarar vermediğini düşünüyordu. Bu durum sigara içen bireylerin, diğer kişilere zarar vermeyeceğini düşünerek, kendi içtiği sigara dumanından çevresindekileri korumak için hassasiyet göstermeyeceği anlamına gelebilir.

Son 30 gün içinde sigaranın zararları ya da bırakma ile ilgili bilgi fark eden öğrencilerin kitle iletişim araçlarından en çok televizyon sonra da internet kullanımı sırasında fark ettikleri görülmektedir. Literatürde televizyonda yayınlanan filmler, medyada yer alan haber, yazı, makale okuma gibi dışsal uyaranların öğrencilerin sigara bırakmasında olumlu etki gösterdiği belirtilmektedir ${ }^{(43,44)}$. Küresel tütün araştırmalarında da sigara içen ve içmeyen iki grupta televizyonun etkisinin önemi ortaya çıkmıştır ${ }^{(16)}$.

Transteoretik Model Değişim Aşaması'na göre değerlendirildiğinde öğrencilerin hemen hemen yarısının düşünmeme, diğer yarısının düşünme ve hazırlık aşamasında olduğu belirlendi. Literatürde sigara bırakmayı düşünmeyenlerin oranı \%48.8-72.6 aralığında değişmektedir ${ }^{(26,32,35,38,42,45)}$. Bu sonuçlar, sigara içen öğrencilere uygulanacak eğitimde, düşünmeme aşamasına yönelik planlamalara ağırlık verilmesi gerektiğini göstermektedir.

Öğrencilerin yarısından fazlası sigara bırakmaya özendiren faktörlerden sağlık sorunlarını belirtti. Literatürdeki araştırmalarda da mevcut sağlık sorunları/sağlık ile ilgili gelecek endişelerinin özendirici olarak görüldüğü belirtilmektedir ${ }^{(26,32,42,45,46)}$. Bu çalışmada, sigara bırakmaya teşvik eden faktörler içinde sağlık sorunlarından sonra en sık belirtilen faktör sigara fiyatlarıydı. Bununla birlikte, ekonomik durumunu düşük olarak belirtenlerde sigara içme oranının yüksek olması aylık sigara harcamasının bütçeye zarar verdiğini göstermektedir.

Öğrencilerin \%58.4'ü sigaraya bağımlı olmadığını düşünürken Fagerström Nikotin Bağımlılık Testi'ne göre öğrencilerin $\% 90.8^{\prime} i$ orta ve yüksek düzeyde sigara bağımlısıydı. Benzer diğer araştırmalarda, öğrencilerin bağımlılık düzeyleri bu araştırmaya göre daha düşük düzeyde bulunmuştur $(21,29,41,43)$. Öğrencilerin sigara bağımlılıkları kullanılan testle yüksek çıktığı halde, kendilerinin bağımlı olmadığını düşünmesi sigaraya yönelik bireysel farkındalıklarının düşük olduğunu göstermektedir. Öğrencilerin yaşlarına bağlı olarak yetişkinlere göre daha az süre sigara içmelerine rağmen, bağımlılık oranlarının yüksek olması geleceğe yönelik sigara ile ilgili daha fazla maruziyet ve dolayısıyla sağlık sorunu ile karşılaşacaklarını akla getirmektedir.

Bu çalışmada, cinsiyet, gelir düzeyi, yaşanılan yer ve 
çalışma durumunun sigara içme prevalansını etkilediği belirlendi. Çalışma sonuçlarına paralel olarak literatürde erkeklerdeki sigara içme oranının kızlara göre daha yüksek olduğu görülmektedir (27,28,3234,40,43,47,48). Bu çalışmada, düşük gelir düzeyine sahip öğrencilerin sigara içme prevalansı daha yüksek bulundu. Literatürde düşük gelir düzeyine sahip öğrencilerin daha fazla sigara içtiğini belirten araştırmalar bulunurken ${ }^{(28,33,43)}$, gelir düzeyi yüksek olanlarda daha yüksek olduğunu gösteren araştırmalar da bulunmaktadır ${ }^{(23,47,48)}$. Bu çalıșmada, öğrenci evinde yaşayan öğrencilerin sigara içme oranının yüksek, yurtta kalanların düşük olması literatürle benzerlik göstermektedir ${ }^{(33,34,40,43,47,48)}$. Çalışmada ayrıca, ücretli bir işte çalışan öğrencilerde sigara içme oranı çalışmayanlara göre daha yüksek bulundu, bu sonuç literatürle paralellik göstermektedir ${ }^{(32,43,47)}$.

Sigara, kronik obstrüktif akciğer hastalığı, akciğer kanseri ve astım başta olmak üzere pek çok akciğer hastalığı için risk faktörüdür. Bu çalışmaya katılan kronik astımlı 22 öğrenciden dördünün sigara içtiği belirlendi. Ayrıca 11 astımlı öğrencinin evde veya okulda ikincil sigara dumanına maruz kaldığı görüldü. Literatürde sigara içen astım ve obstüriktif akciğer hastalarında yapılan solunum fonksiyon testlerinde solunum kapasitesinin azaldığı belirtilmektedir (49). Sigara içme süresi ile solunum fonksiyonları arasında negatif bir ilişki söz konusudur, sigara içme süresi arttıkça solunum fonksiyonlarında bozulmalar da artacağından ${ }^{(50)}$ özellikle bu öğrencilerin zaman kaybetmeksizin sigara ve ikincil sigara dumanından korunması gerekmektedir. Bu konuda yapılacak olan çalışmalarda, kronik hastalıklı olan öğrencilere öncelik verilebilir.

\section{SONUÇ}

Çalışmada, sağlık bilimleri fakültesi öğrencilerinin sigara içme oranı \%13.9 bulundu. Öğrencileri sigaraya teşvik eden faktörlerin arasında etraftaki sigara içen bireyler, arkadaş teşviki ve merak duyguları olduğu belirlendi. Nikotin bağımlılık puanları yüksek olması fakat kendilerini bağımlı hissetmemelerinden dolayı kişisel farkındalıklarının düşük olduğu ve çoğunluğunun bırakmayı düşünmediği görüldü. Erkekler, çalışanlar, düşük gelir düzeyine, boşanmış ebeveynlere sahip öğrenciler, öğrenci evinde yaşayanlarda sigara içme diğerlerine göre yüksekti.lkincil sigara dumanına en çok maruz kalınan yerlerin kaferestoran, okul ve evler olduğu görüldü. Bu sonuçlar doğrultusunda;

Sigaraya başlama konusunda riskli olan üniversitenin ilk yılında sigara önleme, ikincil ve üçüncül sigara dumanı maruziyeti ve bırakma konusunda eğitimler planlanması önerilir. Bu programlarda kronik hastaIıklı olan öğrencilere öncelik verilmelidir.

Sigara içmeyen öğrenciler için; sigara önleme programlarında, merak ve arkadaş özendirmesine karşı öğrencilerin güçlendirilmesi, ikincil sigara dumanı maruziyetinden korunması için okul ve iş yeri gibi mekanlarda, açık alan bile olsa, ortak kullanım alanlarının uygun şekilde düzenlenmesi önerilir.

Sigara İçen Öğrenciler İçin Yapılacak Programlarda; öğrencilerin bağımlıık durumlarının değerlendirmesi ve farkındalıklarının artırılması, sigara bırakmaya yönelik olarak geliştirilmiş olan Transteoretik Model Değişim Aşamaları'na uygun sigara bırakma programlarının yapılması ya da öğrencilerin mevcut programlara yönlendirilmesi önerilir.

Etik Kurul Onayı: T.C. Marmara Üniversitesi Sağlık Bilimleri Enstitüsü Etik Kurul onayı alındı (05.09.2016/69).

Çıkar Çatışması: Yok.

Finansal Destek: Yok.

Hasta Onamı: Alındı.

Ethics Committee Approval: T.C. Marmara University Institute of Health Sciences Ethics Committee approval was obtained (05.09.2016/69).

Conflict of Interest: None.

Funding: None.

Informed Consent: Receipt.

\section{KAYNAKLAR}

1. Bilir N. Sigara ve kanser, Sağlık Bakanlığı Yayını, Ankara: Klasmat Matbaacılık, 2008.

2. Hassoy H, Ergin I, Davas A, Durusoy R, Karababa O. Sağlık meslek yüksek okulu öğrencilerinde sigara, nargile, sarma tütün kullanımını etkileyen faktörlerin belirlenmesi ve öğrencilerin sigara, nargile, sarma tütüne başlama ve sürdürme konusundaki görüşleri. Solunum Dergisi. 2011;13(2):91-9. [CrossRef]

3. Karlıkaya C, Öztuna F, Solak ZA, Özkan M, Örsel O. Tütün kontrolü. Toraks Dergisi. 2006;7(1):51-64.

4. Küresel Yetişkin Tütün Anketi Türkiye. Sağlık Bakanlığı 
Yayını, Ankara: Anıl Matbaacılık, 2012.

5. Mahfouz MS, Alsanosy RM, Gaffar AM, Makeen A. Tobacco Use among university students of Jazan Region: gender differences and associated factors. Biomed Research International, 2014. [CrossRef]

6. World Health Organization, 2010 (WHO). Air Quality Guidelines For Europe.

7. Harlev A, Agarwal A, Gunes SO, Shetty A, DuPlessis SS. Smoking and male infertility: an evidence-basedreview. The World Journal of Men's Health. 2015;33(3):14360. [CrossRef]

8. Kartal M, Mıdık Ö, Büyükakkuş A. Ondokuz Mayıs Üniversitesi Tıp Fakültesi öğrencilerinde sigara kullanımı ve yaşam kalitelerine etkisi. Türk Toraks Dergisi. 2012;13:11-7. [CrossRef]

9. Tuncer DD. Sigaranın Ağız Ve Diş Sağlığı Üzerine Etkileri. Klasmat Matbaacılık, Sağlık Bakanlığı Yayın No: 731, Şubat 2008, Ankara.

10. Ceyhun AG, Bülbül SH. Pasif sigara içiciliği. Türkiye Aile Hekimliği Dergisi. 2007;10(3):123-8.

11. Glantz SA, Parmley WW. Passive smoking and heart disease. Epidemiology, physiology, and biochemistry. Circulation. 1991;83(1):1-12. [CrossRef]

12. Hamer M, Stamatakis E, Batty GD. Objectively assessed secondhand smoke exposure and mental health in adults: cross-sectional and prospective evidence from the Scottish Health Survey. Archives of General Psychiatry. 2010;67(8):850-5. [CrossRef]

13. Samet JM, Yoon SY, World Health Organization (2010). Gender, women, and the tobacco epidemic.

14. World Health Statistics. Geneva: World Health Press, 2012.

15. MMWR Morbidity and Mortality Weekly Report September 10, 2010.

16. Warren CW, Sinha DN, Lee J, Lea V, Jones N, Asma S. Tobacco use, exposure to secondhand smoke, and cessation counseling training of dental students around the world. Journal of Dental Education. 2011;75(3):385-405. [CrossRef]

17. King B. A, Dube SR, Tynan MA. Attitudes toward smoke-free work places, restaurants, and bars, casinos, and clubs among US adults: Findings from the 2009-2010 National Adult Tobacco Survey. Nicotine \& Tobacco Research. 2013;15(8):1464-70. [CrossRef]

18. Martínez-Sánchez JM, Fernández E, Fu M, Gallus $S$, Martínez C, Sureda X, La Vecchia C, Clancy L. Smoking behaviour, involuntary smoking, attitudes towards smoke-free legislations, and tobacco control activities in the European Union. Plos One. 2010;5(11):e13881. [CrossRef]

19. Baykan Z, Naçar M. Tıp fakültesi öğrencilerinin sigara kullanımı ve tütün kanununa ilişkin görüşleri. Dicle Tıp Dergisi. 2014;41(3):483-90. [CrossRef]

20. Eroğlu SA. İstanbul'da Genel Bir Devlet Hastanesinde Çalışanların Sigara İçme Durumu ve Etkileyen Faktörler. İstanbul Tıp Dergisi. 2013;14:170-4.

21. Yengil E, Çevik C, Demirkıran G, Akkoca AN, Özler SG, Özer C. Tıp fakültesi öğrencilerinin sigara içme durumu ve sigara ile ilgili tutumları. Konuralp Tıp Dergisi. 2014;6(3):1-7. [CrossRef]

22. Uysal MA, Kadakal F, Karşidağ C, Bayram NG, Uysal O, Yilmaz V. Fagerstrom test for nicotine dependence: reliability in a Turkish sample and factor analysis. Tüberküloz ve Toraks Dergisi. 2014;52(2):115-21.
23. Çapık C, Cingil D. Hemșirelik öğrencilerinde sigara kullanımı, nikotin bağımlılık düzeyi ve ilişkili etmenler. Kafkas Tıp Bilimleri Dergisi. 2013;3(2):55-61.

24. Karadağ G, Lafçı G. Hemşirelik öğrencilerinin sigara içme durumları ve sağlıklı yaşam biçimi davranışları. Erciyes Üniversitesi Sağlık Bilimleri Fakültesi Dergisi. 2015;3(1):1-15.

25. Pınar ŞE, Cesur B, Bozboğa ZB, Sezer RE. Sivas'ta ebelik öğrencilerinin sigara içme durumları ve ilişkili faktörler. Cumhuriyet Tıp Dergisi. 2011;33(1):10-6.

26. Türker T, Koçak N, Aydın I, İstanbulluoğlu H, Açıkel CH, Kır T, Kılıç $S$. Seçilmiş bir grup tıp fakültesi öğrencisinde sigara içme yaygınlığı ve sigarayı bırakmaya etki eden faktörlerin incelenmesi. Gülhane Tıp Dergisi. 2013;55:207-13.

27. Alexopoulos EC, Jelastopulu E, Aronis K, Dougenis D. Cigarette smoking among university students in Greece: a comparison between medical and other students. Environmental Health and Preventive Medicine. 2010;15(2):115-20. [CrossRef]

28. Eticha T, Kidane F. The prevalence of and factors associated with current smoking among College of Health Sciences Students, Mekelle University in Northern Ethiopia. Plos One. 2014;9(10). [CrossRef]

29. Fabelo JR, Iglesias S, Cabrera R, Maldonado MT. Tobacco and alcohol consumption among Health Sciences Students in Cuba and Mexico. Medical Educatin Cooperation with Cuba Review. 2013;15(4):1823.

30. Koç EM, Başer DA, Döner P, Yılmaz TE, Yılmaz T, Alsancak $A D$, Özkara $A$. Hastane çalışanlarının sigara içme düzeylerinin belirlenmesi ve dumansız hava sahası uygulamasının değerlendirilmesi. Journal of Clinical and Experimental Investigations. 2015;6(1):33-9. [CrossRef]

31. Yüksel S, Cücen Z. Üniversite öğrencilerinde sigara alışkanlığının sorgulanması. Türk Toraks Dergisi. 2012;13(4):169-73. [CrossRef]

32. Eid K, Selim S, Ahmed D, El-Sayed A. Smoking problem among Helwan Universitystudents: Practical versus theoretical faculty. Egyptian Journal of Chest Diseases and Tuberculosis. 2015;64(2):379-85. [CrossRef]

33. Özcebe H, Güçiz Doğan B, İnal E, Haznedaroğlu D, Bertan M. Üniversite öğrencilerinin sigara içme davranışları ve ilişkili sosyodemografik özellikleri. Türk Toraks Dergisi. 2014;15(1):42-8. [CrossRef]

34. Sarıoğlu N, Cüce C, Erel F, Köse M, Arslan M, Bodur AS. Smoking Prevalence and Associated Factors among Students of Balıkesir University. Eurasian Journal of Pulmonology. 2016;18(1):29-34. [CrossRef]

35. Çamur D, Üner S, Çilingiroğlu N, Özcebe H. Bir üniversitenin bazı fakülte ve yüksek okullarında okuyan gençlerde bazı risk alma davranışları. Toplum Hekimliği Bülteni. 2007;26(3):32-8.

36. Onurlubaş $E, Y_{\imath} I d ı z E, Y_{ı} ı l ı z$. Üniversite öğrencilerinin sigara tüketimini etkileyen faktörler: Trakya Üniversitesi öğrencileri üzerine bir uygulama. Uluslar arası Bilimsel Araştırmalar Dergisi. 2017;2(4):83-92. [CrossRef]

37. Baysoy NG. Üniversite öğrenimi sırasında öğrencilerin sağlık riskleri konusundaki bilgi, tutum ve davranışlarındaki değişim. Marmara Üniversitesi Sağlık Bilimleri Enstitüsü, Yüksek Lisans Tezi. 2007.

38. Trotter J. ThePrevalence Of Smoking in Nursing Students. East Tennessee State Üniversitesi. 2014. 
39. Tunçdemir A. Adıyaman Üniversitesi öğrencilerinde sigara içme prevalansı araştırılması. İnönü Üniversitesi Sağlık Bilimleri Enstitüsü, Yüksek Lisans Tezi. 2009.

40. Demirbağ BC, Tavacı S. Sigara içen üniversite öğrencilerinin sosyodemografik özellikleri. Gümüşhane Üniversitesi Sağlık Bilimleri Dergisi. 2012;1(3):179-88.

41. Fernández D, Ordás B, Álvarez MJ, Ordóñez C. Knowledge, attitudes and tobacco use among nursing and physiotherapy students. International Nursing Review. 2015;62(3):303-11. [CrossRef]

42. Türkoğlu M. Adnan Menderes Üniversitesi öğrencilerinin sigara içme ve bırakma davranışlarının değerlendirilmesi. Adnan Menderes Üniversitesi Aile Hekimliği Anabilim Dalı, Uzmanlık Tezi, 2007.

43. Saka G, Şen MA, Yakıt E. Sağlık hizmetleri meslek yüksekokulu öğrencilerinde sigara kullanım sıklığı. Journal of Human Sciences. 2016;13(3):5423-33. [CrossRef]

44. Ulupınar S, Sarıkaya Ö. Sağlık Davranışlarının Geliştirilmesinde Yaşantılayarak Öğrenme Uygulaması. Dokuz Eylül Üniversitesi Hemşirelik Yüksekokulu Elektronik Dergisi. 2009;2(3):95-101.

45. Tan M, Arıkan D, Şahin ZA, Özdemir FK. Kapalı mekânlarda sigara içme yasağının hemşirelik öğrencilerinin sigarayı bırakma durumlarına etkisi. Anadolu Hemşirelik ve Sağlık Bilimleri Dergisi. 2010;14(3):4751.

46. Yararbaş G, Atlam DH. Polis Meslek Yüksekokulu öğrencilerinde sigara kullanımına yönelik görüş ve tutumun değerlendirilmesi. Ege Tıp Dergisi. 2015;54(3):114-9. [CrossRef]

47. Tanrıkulu AÇ, Çarman KB, Palancı Y, Çetin D, Karaca M. Kars il merkezinde çeşitli üniversite öğrencileri arasında sigara kullanım sıklığı ve risk faktörleri. Türk Toraks Dergisi. 2009;11:101-6.

48. Ulukoca N, Gökgöz Ş, Karakoç A. Kırklareli Üniversitesi öğrencileri arasında sigara, alkol ve madde kullanım sıklığı. Fırat Tıp Dergisi. 2013;18(4):230-4.

49. Çapan N. Astım ve Sigara İçimi. Solunum Hastalıkları. 2011;22(2):73-5.

50. Zerin M, Karakılçık AZ, Cebeci B, İriadam M. Üniversite öğrencilerinde kısa ve uzun süre sigara içiminin bazı solunum parametreleri üzerine etkisi. Gaziantep Tıp Dergisi. 2010;16(3):9-12. 